"Sustainability of funded pension schemes: A financial position perspective using options"

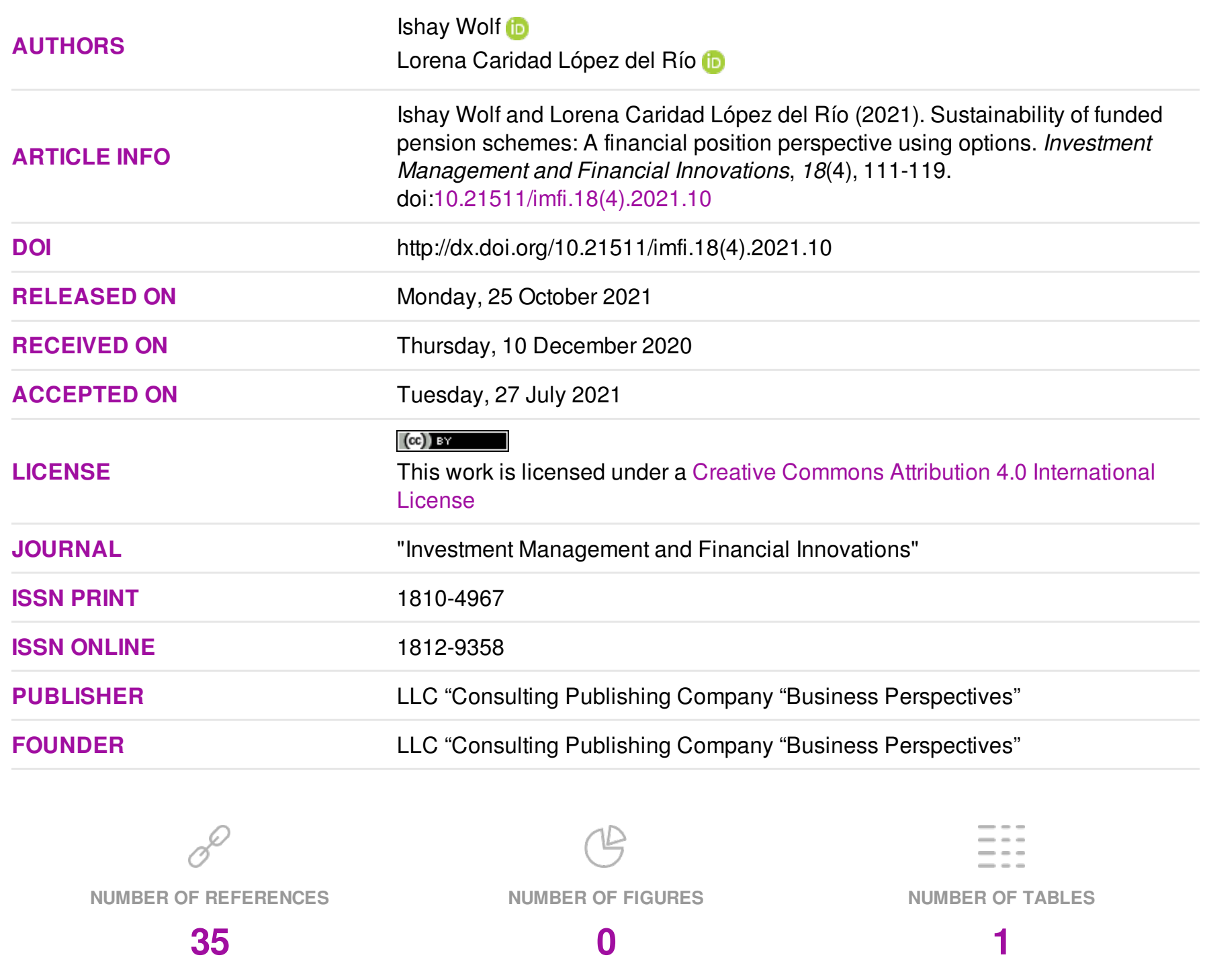

(C) The author(s) 2021. This publication is an open access article. 


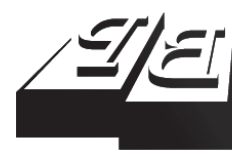

BUSINESS PERSPECTIVES

(O)

LLC "CPC "Business Perspectives" Hryhorii Skovoroda lane, 10, Sumy, 40022, Ukraine www.businessperspectives.org

Received on: $10^{\text {th }}$ of December, 2020 Accepted on: $27^{\text {th }}$ of July, 2021 Published on: $25^{\text {th }}$ of October, 2021

(ㄷ) Ishay Wolf, Lorena Caridad Lopez del Rio, 2021

Ishay Wolf, Doctoral Student, Ono College, Israel. (Corresponding author)

Lorena Caridad Lopez del Rio, Assistant in Statistics and Econometrics, Faculty of Business and Economics, Cordoba University, Spain.

\section{SUSTAINABILITY OF FUNDED PENSION SCHEMES: A FINANCIAL POSITION PERSPECTIVE USING OPTIONS}

\begin{abstract}
This study offers in-depth knowledge of the socio-economic characteristics of funded pension projects. It is based on the financial position of pension market actors during the transition of the pension system to a more funded capitalized scheme, mainly through the option benefit model. This is possible due to the fact that the economy is not viewed as a single earning cohort. The study analytically demonstrates a socioeconomic anomaly in the funded pension system, which is in favor of high-earning cohorts at the expense of low-earning cohorts. This anomaly is realized due to lack of insurance and exposure to financial and systemic risks. Furthermore, the anomaly might lead to the pension re-reform back to an unfunded scheme, mainly due to political pressure. A minimum pension guarantee was found to be a rebalance mechanism to this anomaly, which increases the probability of a sustainable pension scheme. Specifically, it is argued that implementing a guarantee with an intra-generational, risk-sharing mechanism is the most effective way to reduce the impact of this abnormality. Moreover, the paper shows the convergence process toward implementing a minimum pension guarantee in many countries that have capitalized their pension systems during the last three decades, in particular in Latin America and Central and Eastern Europe.
\end{abstract}

Keywords defined contribution, pay-as-you-go, put option, social security

JEL Classification G18, G22, H23, I38

\section{INTRODUCTION}

The latest financial crisis, including the current COVID-19 pandemic, has highlighted the uncertainty of retirement income derived from funded pension plans. Risk protection for retirees has become one of the focuses of the debate on how retirement systems can be organized (Orenstein, 2013; Hacker, 2006). Defined contribution (DC) plans are already the main source of financial retirement in Latin American and CEE countries, while it is expanding rapidly in other countries of Western Europe, where they are still voluntary (Grech, 2015).

Correspondently, the vast literature has observed pressure toward reversals and government insurance in countries that have gone through radical funded reforms (Wolf \& Caridad, 2021b; Altiparmalov, 2018; Naczyk \& Domonkos 2016; Orenstein, 2013). Since the 1990s, developed countries are gradually taken reforms that separate pension systems from the fiscal budget, moving from the public pay-as-you-go (PAYG) defined benefit (DB) model to individual accounts in a multi-pillar architecture. While the literature still studies the reasons for pension reversals, some scholars argue that the unstable pension landscape is due to a lack of risk-sharing mechanisms in these countries, as compared to developed countries (Fultz \& Hirose, 2019; Ebbinghaus, 2015; Grech, 2018). Indeed, according to the late literature, after a rig- 
marole of global experience and debates, the implementation of a minimum pension guarantee has become a key recommendation of global economic organizations as part of the funded modern scheme (e.g., Heneghan, 2019). Moreover, funded pension schemes such as in the Netherlands, Australia and Denmark with strong income redistribution mechanism we witness of sustainability and high adequacy (OECD, 2019).

Using simple financial positions embedded in exchange options, this theory implies a tradeoff between insurance and return in pension designs. This perspective enables the classic economic funding condition of Aaron (1966) to be enriched through the dimension of risk. In addition, this perspective of financial standing allows for differentiation in society. This theory shows that disappointment from the funded scheme may come from low-earning cohorts, while high earners will benefit from the transition. By that, this study confirms Hinrichs (2021), which conclude that fiscal sustainability has the cost of missing the pension purpose of poverty relief. After understanding the gap between financial positions, this paper offers an equilibrium array by providing a minimum pension guarantee financed by intra-generational risk sharing. Thus, one may include this paper in the literature strand of risks in pension schemes (Wolf \& Caridad, 2021a; Chen et al., 2014; Knell, 2010).

The second part of this study focuses on the guarantee cost characteristics, boundaries, constraints, and a favorable way of finance. The challenge of financing the risk-sharing mechanism has become one of the priorities on the agenda of policymakers during the global economic crisis.

\section{THEORETICAL BASIS}

The financial positions of different pension schemes are described using the financial positions of exchange options. After describing the pension market using options, the interests of players are introduced, trying to find an equilibrium point for a sustainable pension design.

\subsection{The pension market}

The final amount of a funded capitalized pension fund can be expressed as a function of the funded asset accumulations $\left(A_{T}\right)$ along with the participant's career, during the working phase, capitalized until death.

$$
D C\left(T_{R}\right)=\tau A_{T}=\sum_{t=1}^{T_{R}-1} \tau w_{t} \prod_{t=1}^{T_{D}-1}\left(1+r_{t}\right),
$$

where $r_{t}$ is the average rate of return earned by the $D C$ plan on its portfolio of financial assets at time $t$. $T_{R}$ is the participant's retirement year, $t=1$ is the time of enrolment in the pension fund, and $T$ is the expected individual's lifetime as this model avoids actuarial factors related to the probabilities of survival. $w_{t}$ is defined as the equivalent gross earnings at the beginning of each year.
The defined benefit (DB) scheme, however, is the function of the participant's wage, working period, and age (Romaniuk, 2009). The individual member is paid at the level of the fund obligations independently from market (asset) performance. Hence, intuitively:

$$
D B\left(T_{R}\right)=\tau L_{T}\left(T_{R}\right),
$$

where, $L_{T}$ is the fund's liabilities. Notably, $C_{L}$ and $P_{L}$ denote the call and put exchange options, respectively, whose payoffs at retirement are as follows:

$$
\begin{aligned}
& C_{T_{R}}=\max (\tau A(T)-L(T), 0), \\
& P_{T_{R}}=\max (L(T)-\tau A(T), 0) .
\end{aligned}
$$

The European put option on the fund assets includes liabilities as of the strike price and a maturity corresponding to the retirement date. The putcall parity in future terms is defined as follows:

$$
C_{T_{R}}-P_{T_{R}}=\tau A(T)-L(T) .
$$

Hence, one can describe the $D B$ scheme as:

$$
D B(T)=L(T)=\tau A(T)+\left(P_{T_{R}}-C_{T_{R}}\right) .
$$


The investment in a defined benefit scheme, and thus, can be replicated by a position composed of three elements: a long position in the fund assets, $A$, long put position, $P_{L}$, and a short call position, $C_{L}$, at the same strike price.

Systematically, the defined contribution's benefits are equal to the investment in a defined benefit fund with the buying call option as $C_{L}$ and selling put option as $P_{L}$ at the same strike price.

$$
D C(T)=D B+\left(C_{T_{R}}-P_{T_{R}}\right) .
$$

One can note that for high-earning cohorts or, more precisely, those who have their total old-age pension accumulation exceeding the former strike price or the average replacement level $(\bar{W} \cdot R R)$, the transition is expected to be beneficial on average, since there is no more cap for their old-age benefits. In contrast, those whose accumulations are expected to be below this level, will be worse off as they are no longer insured by a put option up to a higher benefit level.

The mix/hybrid pension scheme includes two pension pillars: pay-as-you-go (DB PAYG) and a funded DC scheme. Here $\tau$ is the total contribution rate from the participant's wage. The contribution is been split into two components: $\gamma$ as the portion of funded $D C$ from the pension contributions and $(1-\gamma)$ as the contribution share, which finances the $D B$ PAYG.

At retirement, the individual has a benefit position of a hybrid scheme $\left(P N_{T_{R}}^{h y}\right)$ :

$$
P N_{T_{R}}^{h y}=\tau\left\{\gamma A\left(T_{R}\right)+(1-\gamma) L(T)\right\} .
$$

Integrating (6) with (4) results in the following:

$$
P N_{T_{R}}^{h y}=\tau\left\{\gamma A\left(T_{R}\right)+(1-\gamma)\left(A\left(T_{R}\right)+P_{T_{R}}-C_{T_{R}}\right)\right\} \text {. }
$$

That can be reduced to the equation given below:

$$
P N_{T_{R}}^{h y}=\tau\left\{\gamma A\left(T_{R}\right)+(1-\gamma)\left(P_{T_{R}}-C_{T_{R}}\right)\right\}
$$

Equation (8) shows that when the unfunded pillar's contributions are positive, the participant member is willing to pay an insurance premium of $\tau(1-\gamma) C_{L}(T)$ against the adverse accumulation outcomes in a level of $\tau(1-\gamma) P_{L}(T)$.
Hence, efficient insurance effect in a hybrid pension scheme, relative to the $D C$ scheme, accrues when

$$
0<\tau(1-\gamma)<1
$$

After the transition, social security benefits, $L^{\prime}(T)$, are not correlated anymore to the former liabilities level, $L(T)$. They connect with the new social security contributions level, which is a function of wage level, wage growth rate (marked by $q$ ) and the contribution rate to the first pillar. Equation (10) describes the difference between the two unfunded types of pillars' benefits, before and after the pension transition:

$$
\begin{aligned}
& L(T)=\sum_{i=1}^{N} \sum_{t=1}^{T} w_{i, t}(1+q)^{t-1} \cdot R R, \\
& L^{\prime}(T)=\sum_{i=1}^{N} \sum_{t=1}^{T} \tau(1-\gamma) w_{i, t}(1+q)^{t-1}(1+n)^{t-1},
\end{aligned}
$$

where, $R R$ represents the average replacement rate level of the $D B$ pension scheme. The actual old-age benefit in a mixed scheme with the new social security level can be described as follows:

$$
P N_{T_{R}}^{h y^{\prime}}=\tau \gamma A\left(T_{R}\right)+L^{\prime}(T) .
$$

This multi-pillar scheme is in line with the World Bank model (1994). The difference between the actual benefit after the transition (11) and the individual's benefit expectation is noted in (8). This difference creates an expectation gap, leading to an anomaly for pension benefits for low-earning cohorts. This theory is discussed in the next subsection.

Continuing to analyze the transition from an individual perspective, the change in the pension benefit at retirement is as follows:

$$
\begin{aligned}
& \Delta(\text { Pension Financial Position })= \\
& =P N_{T_{R}}^{h y^{\prime}}-D B, \\
& \Delta(\text { Pension Financial Position })= \\
& =\tau \gamma A\left(T_{R}\right)+L^{\prime}(T)-L(T) .
\end{aligned}
$$

At the macro-economic level, the government's net flow of old-age social transfers to the public is summed up to: 


$$
\begin{aligned}
& \Delta(\text { Gov. Net Flow })= \\
& =\text { Expenditures }- \text { Re venues } .
\end{aligned}
$$

- The change in the government's revenues from the transition is the following:

$$
-\gamma \tau \sum_{i}^{n+1} w_{t+1}
$$

- The change in the government's expenditures from the transition is as follows:

$$
L^{\prime}(T)-L(T)
$$

Hence, if the contribution rate is constant during the transition, one can determine the following:

$$
\begin{aligned}
& \Delta(\text { Gov. Net Flow })= \\
& =L^{\prime}(T)-L(T)+\gamma \tau \sum_{i}^{n+1} w_{t+1} .
\end{aligned}
$$

During the pension reform toward funded-capitalized design, one can assume that the individuals' total benefit from the transition (as described in equation (13)) is higher than the government fiscal savings (as described in equation (15)). Otherwise, the central planner would not reform the pension system in the first place, due to political pressure (Grech, 2018; Holzmann \& Hinz, 2005).

$$
\begin{aligned}
& \Delta(\text { Pension Position }) \geq \\
& \geq \Delta(\text { Gov. Net Expenditures Flow }) .
\end{aligned}
$$

Hence, according to (13) and (15),

$$
\begin{gathered}
A\left(T_{R}\right)>\sum_{i}^{n+1} w_{t+1} . \\
\sum_{i=1}^{N} \sum_{t=1}^{T} w_{i, t}(1+r)^{t-1} \geq \\
\geq \sum_{i}^{n} \sum_{t=1}^{T} w_{i, t}(1+n)^{t-1}(1+q)^{t-1} .
\end{gathered}
$$

From the central planner perspective, the transition is worth right if the following holds:

$$
\sum_{i=1}^{T}(1+r)^{t-1} \geq \sum_{i=1}^{T}(1+n)^{t-1}(1+q)^{t-1} .
$$

Equation (19) represents the rationale of pension transitions from the economy level and is sim- ilar to Aaron's (1966) condition, considering the transitioning to the funded scheme from PAYG $(r>n)$. According to the analysis above, the rule is also true for the transition to a mix/hybrid scheme as the condition does not depend on pension pillars' contribution rates.

Equation (19) corresponds to the former World Bank view (2004) and early macro-economic literature on pension reforms in aging economies (Feldstein, 1997, 2001; Disney, 2000) while ignoring risk and individual preference. The option model above was utilized to consider the different actors' interests through their financial position.

\subsection{The government perspective}

The government considers two separate interests. Fiscally, as an active actor in the field, shifting from a PAYG pension design to individual accounts is worth it as it liberates the government from fiscal and longevity risks burden. These risks are transferred individually or in collective pools to the participants.

From a public perspective or the government as a central planner, the transition is worth only if the condition in equation (19) is valid. In addition, the public perspective might include some social targets such as income redistribution and reduction of the income-inequality level. These considerations might push for changes in the transition.

\subsection{The participant's perspective}

The individual's financial position after the transition is given by equation (12). An individual benefits from the transition if:

$$
\begin{aligned}
& \tau \gamma A\left(T_{R}\right)+L^{\prime}\left(T_{R}\right)- \\
& -\left(\tau A\left(T_{R}\right)+P_{T_{R}}-C_{T_{R}}\right)>0 .
\end{aligned}
$$

By reducing the total population indexation, one can determine that, on average, the individual participant gains from the transition if the following is valid:

$$
\begin{aligned}
& \tau(1-\gamma) w_{i, t}\left\{\left(1+q_{t}\right)^{t-1}\left(1+n_{t}\right)^{t-1}-\left(1+r_{t}\right)^{t-1}\right\}+ \\
& +C_{T_{R}}-P_{T_{R}}>0
\end{aligned}
$$


The phrase in the large curly brackets is negative but should be very close to zero as in the long term: $\left(1+r_{t}\right)^{t-1}=\left(1+q_{t}\right)^{t-1}\left(1+n_{t}\right)^{t-1}$. Consequently, one can determine that in average, the individual benefits from the transition if:

$$
C_{T_{R}}-P_{T_{R}}>0
$$

In that case, only those whose long call option is "in the money" and whose short put option position is "out of the money" will gain from the transition; in absolute terms, their pension accumulation is above the average threshold level $(\bar{W} \cdot R R)$. They may gain in average from the transition. Hence, the question of the individual gains from the transition depends on their wage level along with their career and the market yield. If the individual's wage is relatively low, he must be extensively exposed to market risk to gain from the transition. One can think of the funded transition that two components were abolished: for lower earners the insurance component and for high earners the cap for benefits. Although the compensation to market risk provides an expectedly higher yield than the GDP per capita, participants averse to risk might avoid high exposure to market fluctuations (Wolf \& Caridad, 2021b). That tendency is crucial when the individuals' accumulations are not high. Even if it is assumed that all the participants share the same risk aversion coefficient, the total risk appetite depends on total accumulations (Rappaport, 2016; De Menil et al., 2006; Masten \& Thogensen, 2004).

In further discussion, low and high earners are defined according to the absolute strike price. It can be determined that the pension transition is biased in favor of high earners compared to low earners. The extent of the bias depends on the dispersion of benefits above and beneath the former strike price. The lower an individual's accumulation, the worse his financial position after the transition, and vice versa.

\section{RESULTS}

The theory studied above points out a clear financial interest that is pushing toward a funded-capitalized transition. If the average market's yield is high enough, according to the condition illus- trated in (19), there is a chance of actual transition. However, the sustainability of the transition depends on political pressure. If most of the people benefit from the transition, according to the condition described in (21), the new system may be sustainable. Alternatively, if a critical mass of participants is worse off after the transition, political pressure might push toward pension reversals (Grech, 2018; Orenstein, 2013; Ebbinghaus, 2019). This study discusses the re-reforms pension wave of the last two decades back toward the PAYG scheme, mainly in the CEE and Latin American countries.

In an attempt to reduce the probability of pension reversal, the government has an incentive to increase pension accumulations to the low tail of accumulation distribution. If more people benefit from the transition, the probability of keeping the transition sustainable would be higher (Wolf \& Caridad, 2021b; Zaidi, 2010). To this consideration, one may add public social targets of poverty alleviation and income redistribution. In reality, the government is a central planner and mediator that enables financial transactions by implementing a minimum pension guarantee (also called the "zero pillar").

The central planner may finance the guarantee by increasing the contributions to the working population, levying the cost on the younger generation, or by financing the same generation. Since, after the transition, the financial position of a high-earning cohort would be better than a low-earning cohort, determining an intra-generational compensation (minimum guarantee) would be straightforward. The solution to this kind of "externalities" was discussed in Wolf and Caridad (2021a), which included welfare and preferences among cohorts.

In addition, in the era of aging societies, it is not advisable to lean on younger cohort financing. Economically, it would be efficient for every generation to compensate according to its poverty rate and income dispersion.

The model presented above implies further characteristics of the minimum pension guarantee mechanism. The guarantee is attributed as a long put option on behalf of an individual. While hold- 
ing this position, the lower the pension accumulation, the higher the insurance effect. Consequently, the guarantee's cost is simply the discounted value of the benefits from the option, discounted at the government's risk-free rate (Grande \& Visco, 2009). An overview of the main parameters influencing the guarantee cost exchange option perspective is as follows:

\section{A. The underlying asset}

After the transition, the social security pillar and the funded pillar substitute the former DB PAYG pension scheme. Hence, the underlying asset changes from wage level to total pension accumulations from both pillars. Consequently, it is argued that any insurance must be examined and related to the overall benefits and in absolute terms. An example of this kind of guarantee relative to total pension accumulation is implemented in Denmark (Jensen et al., 2019).

\section{B. Guarantee line}

As discussed above, the guarantee economic rationale serves the condition in which enough participants must gain from the transition to avoid political pressure toward another pension reform (Orenstein, 2013). Similar to the put option, when the exercise price is higher, the guarantee cost increases (Lachance \& Mitchell, 2003). At the edge case, when the guarantee line is determined at the average " $R R$ " level, the pension system is practically back to the DB pension scheme. Hence, it is assumed that the guarantee's exercise price cannot pass that line.

Finding the minimum effective strike price is challenging as it depends on a variety of parameters. Due to social concerns, some countries may mark the poverty line as a floor that ensures a proper standard of living in old age (Grande \& Visco, 2010; Pennachi, 2009). The poverty line might be high enough to keep the transition sustainable, but it also depends on other variables that change from time to time such as the dispersion level and the market's yield. Hence, it can be claimed that the government must react to macro-economic changes. For example, the permanent reduction in the average rate of return should lead to considering an increase in the guarantee's strike price.

\section{Pension pillar sizes}

While increasing the funded pillar's weight within the pension system, the individual's exposure to financial risk increases. Consequently, two contradictory factors influence the guarantee cost's return and risk:

- Funded Pension's Rate of Return: Naturally, as the average pension return is higher, there is more probability that the individual's old-age benefit exceeds the guarantee threshold and there are lesser chances that the put option would be exercised. Hence, intuitively, when the average return is higher, the expected guarantee cost is lower.

- The Volatility Influence: With higher funded pillar weight, the portfolio accumulation of pension benefits and the standard deviation increases as $\sigma_{A}>\sigma_{W}$. Following the BlackScholes option pricing model, a higher pension portfolio's volatility increases the guarantee cost. Hence, the "financial" position of the state, as the writer of the option, is under more stress.

Naturally, the above conclusions are opposite if the unfunded pillar's weight increases. Summing the return and the volatility influences, there is no clear conclusion whether the guarantee cost will increase when the funded scheme increases. This is in line with Barr and Diamond (2009), who argued against the pension literature strand during the 1990s that pushed to implement funded pension funds to decrease fiscal burdens.

\section{Market yields}

A higher rate of return, $r$, increases the underlying asset's value and, accordingly, reduces the put option value/cost. On the other hand, the GDP per capita does not influence the guarantee cost, since both the strike price and the underlying asset are indexed to the GDP per capita.

\section{E. Income dispersion}

Statistically, with high-income inequality, there is a higher probability that individuals' put options will be exercised at retirement. As a consequence, 
the total guarantee cost in the market will be higher. In a theoretical case where there is a flat dispersion of accumulation around the RR level, flows from high-earning cohorts to low-earning cohorts can imitate the DB pension scheme, bringing all participants to the RR average point in absolute financial terms. In the common case with income inequality, the burden of the guarantee cost is distributed among fewer participants, and naturally, its exercise price is lower than the average RR level.

\section{F. Average age}

In line with the Black-Scholes pricing model, the put option's value decreases when the exercise date approaches. Therefore, it was found that there is a negative correlation between the average dependency ratio in society and the total guarantee cost at a given point in time.

Table 1 summarizes the correlation between the guarantee cost and the above parameters.

Table 1. The influence on the guarantee cost

\begin{tabular}{l|c}
\hline \multicolumn{1}{c|}{ Parameter } & $\begin{array}{c}\text { Influence on the } \\
\text { guarantee cost }\end{array}$ \\
\hline The guarantee line & + \\
\hline The funded pillar's size & $?$ \\
\hline The market's rate of return & + \\
\hline GDP per capita rate of return & + \\
\hline Income inequality level & + \\
\hline Dependency ratio & - \\
\hline
\end{tabular}

\section{DISCUSSION}

Pension reversals have accelerated during the last years, mainly after the post-2008 crisis and the recent COVID-19 financial crisis (Fultz \& Hirose, 2019; Wolf \& Caridad, 2021b). As there are different reasons for the pension evolution in each country, global experience confirms that the demand for redistribution mechanisms or minimum pension guarantee are common motives in the late design of pension reforms around the globe. These mechanisms can address the form of pension top-ups, such as in Argentina and Poland, or for instance, a zero pillar in places such as Chile, Hungary, and Kazakhstan.

The model introduced above argues that the question of the pension reform sustainability is linked to the economic gain/loss of participants and not necessarily to the rate of return and the population coefficient growth, similar to what used to be addressed in the traditional economy (Aaron, 1966). The model asserts that the Aaron-Samuelson rule is valid in an economy with identical consumers or, at least, almost homogenous savers. In reality, the question of pension reform depends on statistical-political considerations. According to the above model, if a significant mass of participants will be negatively affected by the transition, the probability of reversal is higher. The option model above clearly depicts that, economically, for low-earning cohorts whose old-age benefits are below the average, the replacement rate is negatively affected by the pension transition. The lower their average pensions accumulate below the former average replacement rate and/or the more the number of participants below the average replacement, the more the sustainability of the funded pension reform is at stake. To implement pension guarantee signals, all the earning cohorts must trust the pension system at retirement, despite the various risks of burden. According to this model, the central planner has to improve the financial benefit status of enough participants to maintain the pension scheme. Hence, the guarantee's strike price, if implemented, should be necessary below the former average replacement rate.

To lower the guarantee cost, the central planner must alleviate the inequality level in society. Only then can the guarantee strike price be increased and its cost distributed among a larger group of participants.

\section{CONCLUSION}

This study aimed to provide extensive knowledge on the socio-economic characteristics of funded pension projects. This was done through an analysis of the old-age benefits offered during the transition from the DB PAYG pension scheme to the funded design. The results of the theoretical model demon- 
strate that the transition is beneficial, mainly for high-earning cohorts at the expense of low-earning cohorts. Moreover, implementing a minimum pension guarantee was revealed as an efficient way to increase the probability of the pension system's sustainability. The special characteristics of the guarantee boundaries and their cost were explored in this study.

The results show that the consideration of the validity of pension transition as the function of aging and return is limited. It was claimed that a sustainable funded pension scheme is a function of the participants' economic benefit level in old age and not necessarily of the market's rate of return. Moreover, in agreement with the emerging literature on pension reforms and re-reforms, it was claimed that in a funded pension scheme, the central planner has an incentive to implement a minimum pension guarantee, avoiding cyclical pension reforms and fiscal risks while leaning on unfunded pillars.

From that perspective, implementing the guarantee through intra-generational risk sharing can effectively reduce the anomaly stated earlier. That kind of guarantee can be considered as a 'physical' "collar" transaction, where the underlying asset is the total old-age benefit at retirement. Economically, this transaction compensates low earners for their lack of insurance for low benefits and high exposure to financial risks with low ability to diversify them.

Countries that impose funded schemes with low public pillar and insufficient social protection, such as Israel, Ireland, and the U.K. can utilize this study to implement social protection while considering the experience of most other countries. According to the insurance expectation theory described above, the timing of expected re-reforms in these countries is correlated to the timing of the first waves of retirees under the new pension scheme. The last financial crisis, including the recent COVID-19 pandemic and poor performance of funded pension funds, might foster new pension reforms. It is worth investigating this process in the future.

\section{AUTHOR CONTRIBUTIONS}

Conceptualization: Ishay Wolf, Lorena Caridad López del Río.

Data curation: Ishay Wolf.

Formal analysis: Ishay Wolf, Lorena Caridad López del Río.

Funding acquisition: Ishay Wolf, Lorena Caridad López del Río.

Investigation: Ishay Wolf.

Methodology: Ishay Wolf, Lorena Caridad López del Río.

Project administration: Ishay Wolf.

Resources: Ishay Wolf.

Validation: Lorena Caridad López del Río.

Writing - original draft: Ishay Wolf.

Writing - review \& editing: Lorena Caridad López del Río.

\section{REFERENCES}

1. Aaron, H. (1966). The Social Insurance Paradox. Canadian Journal of Economics and Political Science, 32(3), 371-374. https://doi. org/10.2307/139995

2. Acuña, R., \& Iglesias, A. (2001). Chile's pension reform after 20 years (Working paper 0129). Washington, DC: The World Bank.

3. Altiparmakov, N. (2018). Another look at causes and consequences of pension privatization reform reversals in Eastern Europe. Journal of European Social Policy, 28(3), 224 241. https://doi.org/10.1177\%2F095 8928717735053

4. Antolín, P., Payet, S., Whitehouse, E., \& Yermo, J. (2011). The Role of Guarantees in Defined Contribution Pensions (OECD Working Papers on Finance, Insurance and Private Pensions, No. 11). OECD
Publishing, Paris. https://doi. org/10.1787/5kg52k5b0v9s-en

5. Barr, N., \& Diamond, P. (2009). Reforming pensions: Principles, analytical errors and policy directions. International Social Security Review, 62(2), 5-29. https://doi.org/10.1111/j.1468246X.2009.01327.x

6. Barr, N., \& Diamond, P. (2016) Reforming Pensions in Chile. 
Polityka Społeczna, 1, 4-8. Retrieved from https://economics.mit.edu/ files/12427

7. Chen, D., Beetsma, R., Ponds, E., \& Romp, W. (2014). Intergenerational Risk-Sharing Through Funded Pensions and Public Debt. Journal of Pension Economics and Finance, 15(2), 127-159. https://doi. org/10.1017/S1474747214000365

8. Datz, G., \& Dancsi, K. (2013). The politics of pension reform reversal: a comparative analysis of Hungary and Argentina. East European Politics, 29(1), 83-100. https://doi.or g/10.1080/21599165.2012.759940

9. Ebbinghaus, B. (2015). The Privatization and Marketization of Pensions in Europe: A Double Transformation Facing the Crisis. European Policy Analysis, 1(1), 56-73. https://doi.org/10.18278/ epa.1.1.5

10. Ebbinghaus, B. (2019). MultiPillarization Remodelled: the Role of Interest Organizations in British and German Pension Reforms. Journal of European Public Policy, 26(4), 521-539. https://doi.org/10.10 80/13501763.2019.1574875

11. Feldstein, M., \& Ranguelova, E. (2001). Individual Risk in an Investment-Based Social Security System. The American Economic Review, 91(4), 1116-1125. Retrieved from https://www.aeaweb.org/ articles?id=10.1257/aer.91.4.1116

12. Giorno, C., \& Jacques, A. (2016). Improving the Pension System and the Welfare of Retirees in Israel (OECD, Working Paper No. 1288). Paris: OECD Publishing.

13. Guardiancich, I. (2011). PanEuropean pension funds: Current situation and future prospects. International Social Security Review, 64(1), 15-36. Retrieved from https:// papers.ssrn.com/sol3/papers. cfm?abstract_id $=1735313$

14. Grande, G., \& Visco, I. (2010). A Public Guarantee of a Minimum Return to Defined Contribution Pension Scheme Members. The Journal of Risk, 13(3), 3-43. http:// dx.doi.org/10.21314/JOR.2011.226

15. Grech, A. G. (2015). Convergence or divergence? How the financial crisis affected European pensioners. International Social Security Review, 68(2), 43-62. https://doi. org/10.1111/issr.12065
16. Hinrichs, K. (2021). Recent pension reforms in Europe: More challenges, new directions. An overview. Social Policy and Administration, 55(3), 409-422

17. Holzmann, R. (2013). Global pension systems and their reform: Worldwide drivers, trends and challenges. International Social Security Review, 66(2), 1-29. Retrieved from https://www.iza. org/publications/dp/6800/globalpension-systems-and-their-reformworldwide-drivers-trends-andchallenges

18. Holzmann, R., \& Hinz, R. (2005). Old-Age Income Support in the 21st Century: An International Perspective on Pension Systems and Reform. The World Bank. https://doi org/10.1596/0-8213-6040-X

19. Hujo, K., \& Ralli, M. (2014). The political economy of pension re-reform in Chile and Argentina: Toward more inclusive protection. United Nations Research Institute for Social Development.

20. Jensen, S., Pedersen, T., \& Foxman, T. (2019). Experiences with Occupational Pensions in Denmark Quarterly Journal of Economic Research, 88(1), 11-30.

21. Muir, D., \& Turner, A. (2011). Constructing the Ideal Pension System: The Visions of Ten Country Expert. UPJOHN Institute for Employment Research. Retrieved from https://research.upjohn.org/ up_bookchapters/795/

22. Naczyk, M., \& Domonkos, S. (2016) The Financial Crisis and Varieties of Pension Privatization Reversals in Eastern Europe. Governance, 29(3), 167-184. http://dx.doi.org/10.1111/ gove.12159

23. Natali, D. (2018). Recasting Pensions in Europe: Policy Challenges and Political Strategies to Pass Reforms. Swiss Political Science Review, 24(1), 53-59. https:// doi.org/10.1111/spsr.12297

24. Nelson, K., Nieuwenhuis, R., \& Alm, S. (2019). Sweden: Adjoining the Guarantee Pension with NDC. Social Protection Discussion Papers and Notes from The World Bank.

25. OECD (2019). Pensions at a Glance 2019: OECD and G20 Indicators. Paris: OECD Publishing. https://doi. org/10.1787/b6d3dcfc-en
26. Orenstein, M. A. (2013). Pension Privatization: Evolution of a Paradigm. Governance, 26(2), 259-281. https://doi.org/10.1111/ gove. 12024

27. Pennachi, G. G. (1999). The value of guarantees on pension fund returns. Journal of Risk and Insurance, 66(2), 219-237. https:// doi.org/10.2307/253610

28. Romaniuk, K. (2009). The Options Embedded within Pension Plans: Types, Valuation Principles and Effects on Optimal Investment Policies. Bankers, Markets \& Investors, Forthcoming. Retrieved from https://ssrn.com/abstract $=1618324$

29. Smetters., K. (2002). Controlling the cost of minimum benefit guarantees in public pension conversions. Journal of Pension Economics and Finance, Cambridge University Press, 1(1), 9-33. https://doi.org/10.1017/ S1474747202001014

30. Wolf, I., Caridad y Lopez del Rio, L. (2021a). Funded-capitalized pension designs and the demand for minimum pension guarantee. Public and Municipal Finance, 10(1), 12-24. https://doi.org/10.21511/ pmf.10(1).2021.02

31. Wolf, I., \& Caridad y Lopez Del Rio, L. (2021b). Pension Reforms and Risk Sharing Cycle: A Theory and Global Experience. International Journal of Economics \& Business Administration (IJEBA), 9(1), 225 242. Retrieved from https://www. ijeba.com/journal/669

32. World Bank. (1994). Averting the old age crisis: Policies to protect the old and support growth. New York, NY, Oxford University Press.

33. World Bank. (2009). Pensions in crisis: Europe and Central Asia regional policy note. Washington, DC.

34. World Bank. (2010). Pensions. Washington, DC, World BankSocial Protection and Labor.

35. Zaidi, A. (2010). Fiscal and Pension Sustainability: Present and Future Issues in EU Countries. European Center. Belgian EU Presidency. Retrieved from https://core.ac.uk/ download/pdf/11867528.pdf 